\title{
Nuruddin Ar-Raniry: Kajian Pemikiran Tokoh Muslim Indonesia
}

\section{Muhammad Fayrus}

Program Magister Studi Islam, Universitas Paramadina

\section{Abstract}

In the Nusantara archipelago, the process of Islamization began with port cities which were at the same time the royal capital, such as Samuera Pasai and Malacca, which later became the center of the royal palace which became the center of Islamic intellectual development over the official protection of the rulers, followed by the emergence of clerical figures such as Hamzah Fansuri, Samsuddin as-Sumatrani, Nuruddin Ar-Raniry, and Abdur Rauf as-Singkili in the Aceh kingdom. While in Java there is Wali Songo. 2 These great ulamas were credited with spreading Islamic knowledge in Southeast Asia and later established Islamic educational institutions such as dayahs so that a university in Aceh developed.

\author{
Keywords \\ Nusantara; Islam Pasa;; Malaka; Ar- \\ Raniry, Aceh

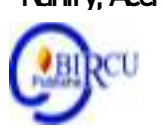

\section{Pendahuluan}

Dalam sejarah banyak menceritakan bahwa Aceh salah satu daerah yang sangat strategis, sehingga tidak mengherankan lagi apabila banyak orang asing ataupun para pedagang yang melewati atau singgah di Aceh. Mereka datang dari berbagai bangsa, Hindia, Gujarat, dan lain-lainnya. Dengan demikian, tidak salah bahwa orang Aceh mayoritasnya keturunan campuran. Selain itu, dengan singgahnya orang asing atau lewatnya para pedagang tersebut, maka terjadilah kontak antara orang Aceh dengan mereka tersebut. Sehingga melahirkan peradaban dan kebudayaan serta terjadinya transmisi dalam hal keagamaan. ${ }^{1}$

Di Nusantara, proses Islamisasi berawal dari kota-kota pelabuhan yang sekaligus jadi ibukota kerajaan, seperti Samuera Pasai dan Malaka, yang kemudian menjadi pusat istana kerajaan yang menjadi pusat pengembangan intelektual Islam atas perlindungan resmi penguasa yang disusul kemunculan tokoh-tokoh ulama semacam Hamzah Fansuri, Samsuddin as-Sumatrani, Nuruddin Ar-Raniry, dan Abdur Rauf as-Singkili di kerajaan Aceh. Sementara di Jawa ada Wali Songo. ${ }^{2}$ Ulama-ulama besar ini banyak berjasa menyebarkan ilmu pengetahuan Islam di Asia Tenggara kemudian mendirikan lembaga-lembaga pendidikan Islam seperti dayah sehingga berkembang semacam perguruan tinggi di Aceh.

Ulama dayah mengajarkan Islam yang telah disesuaikan dengan bentuk kehidupan pendesaan penduduk Aceh, dan secara perlahan membimbing mereka mempraktekkan Islam dalam kehidupan sehari-hari. Dayah juga menjadi pusat pendidikan terorganisasi yang menyebar secara luas hampir ke semua daerah di Aceh. ${ }^{3}$ Nuruddin Ar-Raniry dan Abdur Rauf

\footnotetext{
${ }^{1}$ Abdul Majid, Karakteristik Pemikiran Islam Nuruddin Ar-Raniry, Jurnal Substantia, Volume 17 Nomor 2, Oktober 2015. Fakultas Ushuluddin dan Filsafat, UIN Ar-Raniry, hal. 179

${ }^{2}$ Musyrifah Sunanto, Sejarah Peradaban Islam Indonesia, (Jakarta: PT RajaGrafindo Persada, 2005), hal. 13-14.

${ }^{3}$ Jajat Burhanuddin, Ulama \& Kekuasaan: Pergumulan Elite Muslim dalam Sejarah Indonesia,

(Jakarta: Mizan Publika, 2012), hal. 40.
} 
as-Singkli adalah ulama yang mengajar di lembaga pendidikan ini. Banyak murid dari kerajaan lain belajar dari mereka sehingga Aceh dijadikan sebagai batu loncatan untuk belajar Islam lebih tinggi lagi setelah Aceh yaitu ke Mekkah.

Di Aceh memiliki lembaga khusus yang didesain untuk memberi nasehat kepada raja yaitu Mufti atau Syaikhul Islam berada langsung di bawah raja. Mufti zaman Sultan Iskandar Tsani dan Sultanah Shafiyatuddin adalah Nuruddin ar-Raniry. Jabatan Syaikhul Islam memiliki pengaruh besar dalam pembuatan kebijakan-kebijakan raja dalam masalah sosial dan politik. Misalnya, ketika ar-Raniry mengepalai Syaikhul Islam dilaporkan menengahi protes keras Belanda atas regulasi perdagangan kerajaan yang menguntungkan para pedagang Gujarat. Dengan otoritasnya, ar-Raniry berhasil meyakinkan raja Safiatuddin untuk menarik regulasi tersebut.

Nuruddin Ar-Raniry, merupakan salah satu orang Gujarat yang sangat berperan terhadap perkembangan Aceh prioritasnya dalam bidang keagamaan yang mengambil spesifikasi dalam bidang tasawuf pada sekitar abad ke 17 silam. Dalam hal ini, Ar-Raniry sangat dikenal di Aceh terutama ketika ia menentang paham wujudiyyah Hamzah Fansuri yang menjadi keyakinan masyarakat Aceh pada masa itu.

Oleh karena itu, untuk lebih jelasnya bagaimana kiprah Ar-Raniry dalam menentang paham wujudiyyah Hamzah Fansuri. Di bawah ini, akan dibahas secara lebih mendetil tentang karakteristik pemikiran Islam Nuruddin Ar-Raniry mulai dari biografi, dasar pemikiran, karya-karyanya serta kiprahnya.

\section{Rumusan Masalah}

Diantara permasalahan yang perlu diangkat berkenaan dengan tema ini untuk dicarikan jawabannya adalah sebagai berikut:

a. Bagaimana riwayat hidup Nuruddin Ar-Raniry?

b. Apa saja pemikiran yang dihasilkan oleh Nuruddin Ar-Raniry?

c. Apa saja kiprah Nuruddin Ar-Raniry terhadap penyebaran Islam di nusantara?

\section{Tujuan Penulisan}

a. Untuk mengetahui riwayat hidup Nuruddin Ar-Raniry

b. Untuk mengetahui pemikiran yang dihasilkan oleh Nuruddin Ar-Raniry

c. Untuk mengetahui kiprah Nuruddin Ar-Raniry terhadap penyebaran Islam di nusantara

\section{Kajian Pustaka}

\section{Riwayat Hidup Nuruddin Ar-Raniry}

Syeikh Nuruddin Muhammad ibnu 'Ali ibnu Hasanji ibnu Muhammad Hamid arRaniry al-Quraisyi adalah ulama penasehat Kesultanan Aceh pada masa kepemimpinan Sultan Iskandar Tsani (Iskandar II). Syaikh Nuruddin diperkirakan lahir sekitar akhir abad ke-16 di kota Ranir, sebuah Kota Pelabuhan Tua di Pantai Gujarat, India, dan wafat pada 21 September 1658. Pada tahun 1637, ia datang ke Aceh, dan kemudian menjadi penasehat kesultanan di sana hingga tahun $1644 .{ }^{4}$ Dikatakan ibunya adalah seorang Melayu, tetapi ayahnya berasal dari keluarga imigran Hadhrami yang mempunyai tradisi panjang berpindah ke Asia Selatan dan Asia Tenggara. Paman dari garis ayah, Muhammad Jilani bin Hasan Muhammad al-Humaydi, dating dari Gujarat ke Aceh dia mengajar fiqh, ushul fiqh, etika, logika (manthiq), dan retorika.

\footnotetext{
${ }^{4}$ https://id.wikipedia.org/wiki/Nuruddin_al-Raniri diakses pada tanggal 09 oktober 2016.
} 
Ia mengikuti langkah keluarganya yaitu pamannya dalam hal pendidikan. Pendidikanya yang pertama diperoleh di Ranir kemudian dilanjutkan ke Hadhramaut. ${ }^{5}$ ketika ia berada di Negeri asalnya, ia sudah menguasai banyak tentang Ilmu Agama. Diantara guru yang paling banyak mempengaruhinya adalah Abu Nafs Syayid Imam bin „Abdullah bin Syaiban, ia seorang guru Tarekat Rifaiyah keturunan Hadhramaut Hujarat, India. Gurunya yang paling terkenal adalah Abu Hafs Umar bin Abdullah Ba Syayban alTarimi al-Hadhrami, yang juga dikenal sebagai Sayyid Umar al-Alaydrus. ${ }^{6}$

Setelah mempelajari ilmu-ilmu Islam dan ditunjuk sebagai khalifah Tarekat Aydarusiyah serta Rifa "eiyah, tibalah waktunya bagi ar-Raniry untuk memulai karirnya. Beberapa karyanya dia sangat mengenal dunia Melayu, bahkan sebelum kedatangannya ke nusantara, karena ibunya berasal dari Melayu dan juga pamannya yang sering mengadakan perjalanan pulang-balik ke Aceh yang memberikan informasi mengenai tradisi budaya dan keagamaan Melayu.

Syaikh Nuruddin ar-Raniry datang ke Aceh setelah menuntut ilmu pada guru-gurunya di negeri sendiri, kemudian ia melanjutkannya ke negeri-negeri Arab, tetapi ia lama bermukim di Haramayn, Makkah dan Madinah, sehingga ia menjadi alim. Dalam I tetikad ia menganut paham Ahlussunnah waljama ${ }^{e} a h$, sementara dalam fiqh ia menganut mazhab Syafie ${ }^{\text {i }}{ }^{7}$

Diperkirakan ia dua kali datang ke Aceh. Kedatangan pertama ia tidak lama tinggal karena tidak baik penerimaan oleh tokoh-tokoh aliran wujudiyah yang telah mempengaruhi istana di masa Sultan Iskandar Muda. Kedatangan kedua pada tahun 1636M/1047H, bertepatan dengan tahun wafatnya Sultan Iskandar Muda digantikan oleh menantunya Sultan Iskandar Tsani yang dengan tangan terbuka mengangkatnya sebagai mufti Kerajaan Aceh Darussalam. ${ }^{8}$ Setelah lima tahun memerintah, Sultan Iskandar Tsani wafat pada tahun 1641 M dan digantikan oleh permaisurinya Sultanah Tajul Alam Safiatuddin Syah binti Sultan Meukuta Alam Iskandar Muda. Yang memerintah Aceh sekitar 34 tahun, pada masa inilah Nuruddin ar-Raniry mengarang kitab yang khusus menganalisa ajaran wujudiyah Hamzah Fansury dan muridnya Syamsuddin as-Sumatrani yang berjudul Tibyan fi Ma'rifah al-Dyan.

Dalam tradisi pemikiran keagamaan di Aceh, terutama pada pertengahan abad XVII M, sejarah mencatat fakta telah terjadi kontraversi yang berlarut dan berujung pada pembunuhan pemikiran ajaran tertentu. Ajaran yang dikembangkan Hamzah Fansuri dan Syamsuddin as-Sumatrani memperoleh permusuhan yang tragis dari Nuruddin ar-Raniry. Perlawanan disulut oleh pertentangan ar-Raniry terhadap ajaran kedua ulama penganut paham Ibnu Arabi tentang doktrin wujudiyyah.

Menurut catatan Azyumardi Azra, Ar-Raniry merupakan tokoh pembaruan di Aceh. Ia mulai melancarkan pembaharuan Islam di Aceh setelah mendapat pijakan yang kuat di Istana Aceh. Pembaruan utamanya adalah memberantas aliran wujudiyah yang dianggapnya sebagai aliran sesat. Ar-Raniry dikenal mula sebagai Syekh Islam yang mempunyai otoritas untuk mengeluarkan fatwa menentang Aliran wujudiyah. Bahkan lebih jauh ia

\footnotetext{
5 Ahmad Daudy, Syaikh Nurruddin ar-Raniri: Sejarah, Karya, dan Sanggahan terhadap Wujudiyyah di Aceh, (Bulan Bintang 1983),.hlm. 36-37

${ }^{6}$ Azyumardi Azra, Jaringan Ulama Timur Tengah dan Kepulauan Nusantara Abad XVII dan XVII, (Bandung: Mizan, 1995), hal. 205

7 Sirajuddin Abbas, Ulama Syafi'I dan Kitab-kitabnya dari Abad ke Abad, (Jakarta: Pustaka Tarbiyah, Cet. 1975M), hal. 379.

${ }^{8}$ Mohd. Kalam Daud, "Al-Tibyan fi Maerifah al-dyan, agama-agama Samawi dan sekte-sektenya (Analisis Aliran Wujudiyah Hamzah Fansury) “, (Banda Aceh: PeNA, 2011), hal. 260-261.
} 
mengeluarkan fatwa yang mengarah pada perburuan terhadap orang-orang sesat. ${ }^{9}$

Ar-Raniry dikatakan pulang kembali ke India setelah dia dikalahkan oleh dua orang murid Hamzah Fansuri pada suatu perdebatan umum. Ada riwayat mengatakan dia meninggal di India. Menurut Sirajuddin Abbas, riwayat hidup Syaikh Nuruddin ar-Raniry dapat dijumpai dalam ensiklopedi Ulama-Ulama India berjudul Nuzhah al-Khawatir (dalam bahasa Arab) karangan „Abdul Haj Fakhruddin al-Hasany. Di sini disebutkan Syaikh Nuruddin wafat di kampung halamannya sendiri sekitar tahun $1068 \mathrm{H} .{ }^{10}$

\section{Pembahasan}

\subsection{Hasil Karya Pemikiran Nuruddin Ar-Raniry dan Kiprahnya}

Ar-Raniry adalah alim pertama nusantara yang menulis pegangan standar mengenai kewajiban agama (fiqh) yang mendasar bagi semua orang. Karya tulisnya itu menjadi sangat popular di seluruh nusantara dan masih digunakan di beberapa tempat sampai sekarang. 13

Di antara karya-karya yang pernah ditulis Ar-Raniry adalah :

1) Ash-Shirah Al-Mustaqim (fiqih berbahasa melayu)

2) Bustan As-Salatin fi Dzikir Al-Awwalin wa Al-Akhirin (Bahasa Melayu)

3) Durrat Al-Fara'idh bi Syarhi Al-'Aqa'id ( akidah, bahasa Melayu)

4) Syifa' Al-qulub (cara-cara berzikir, bahasa Melayu)

Karya Ar-Raniry tersebut di atas, sebagian besar berhubungan dengan masalah Tasawuf. Di antaranya berkaitan dengan penolakannya terhadap paham panteisme14 yang di nilainya sesat dan uraian lengkap tentang perdebatan melawan pengikut Fansuri yang menjadi penyebab dikeluarkannya fatwa hukuman mati kepada mereka. Nubzah fi Da'wah az-Zil, misalnya memuat topik pemaparan tentang tasawuf dan merupakan penegasan aliran pemikirannya yang menilai konsep panteisme sesat.

Ar Raniry memiliki pengetahuan luas yang meliputi tasawuf, kalam, fikih, hadis, sejarah, dan perbandingan agama. Selama masa hidupnya, ia menulis kurang-lebih 29 kitab, yang paling terkenal adalah "Bustanus Salatin". Namanya kini diabadikan sebagai nama perguruan tinggi agama (IAIN) di Banda Aceh.

Bustanus Salatin ditulis sekitar tahun 1630-an, didedikasikan kepada pelindungnya, Sultan Iskandar Tsani. Dalam pengantarnya, ar-Raniry menulis bahwa Iskandar Tsani menugaskannya untuk menyusun sebuah buku (kitab) dalam bahasa Melayu (Jawi) terkait perbuatan warga menghubungkan perbuatan para raja di masa-masa awal dan kemudian.

Bustanus Salatin terdiri dari tujuh buku. Dimulai dengan penciptaan dunia, kemudian buku kedua berlanjut dengan sejarah para nabi, para rasul Tuhan, dan para raja dari masa praIslam. Lalu dilanjutkan dengan periode Islam dari masa Nabi Muhammad SAW., sampai kerajaan-kerajaan Islam di India. Buku kedua memuat sejarah Islam di Asia Tenggara, berpusat pada Kerajaan Malaka dan Pahang, didikuti oleh Aceh. Buku berikutnya, buku ketiga sampai keenam, berisi panduan politik dan nasihat bagi para raja, berdasarkan kisahkisah khalifah dan raja di masa lalu. Buku ketujuh, berkaitan dengan prestasi ilmiah dalam bidang firasat, anatomi, dan kedokteran.

Ar-Raniry berperan penting saat berhasil memimpin ulama Aceh menghancurkan ajaran tasawuf falsafinya Hamzah al-Fansuri yang dikhawatirkan dapat merusak akidah umat Islam awam terutama yang baru memeluknya. Tasawuf falsafi berasal dari ajaran Al-Hallaj, Ibn 'Arabi, dan Suhrawardi, yang khas dengan doktrin Wihdatul Wujud (Menyatunya Kewujudan) di mana sewaktu dalam keadaan sukr ('mabuk' dalam kecintaan kepada Allah

\footnotetext{
${ }^{9}$ Azyumardi Azra, Jaringan Ulama, ..., hlm. 177

${ }^{10}$ Sirajuddin Abbas, Ulama Syafi'i, ..., hal. 379.
} 
Ta'ala) dan fana' fillah ('hilang' bersama Allah), seseorang wali itu mungkin mengeluarkan kata-kata yang lahiriahnya sesat atau menyimpang dari syariat Islam.

Maka oleh mereka yang tidak mengerti hakikat ucapan-ucapan tersebut, dapat membahayakan akidah dan menimbulkan fitnah pada masyarakat Islam. Karena individuindividu tersebut syuhud (menyaksikan) hanya Allah sedang semua ciptaan termasuk dirinya sendiri tidak wujud dan kelihatan. Maka dikatakan wahdatul wujud karena yang wajib wujudnya itu hanyalah Allah Ta'ala sedang para makhluk tidak berkewajiban untuk wujud tanpa kehendak Allah. Pada paham wahdatul wujud, dapat di umpamakan seperti satu tetesan air murni pada ujung jari yang dicelupkan ke dalam lautan air murni. Sewaktu itu, tidak dapat dibedakan air pada ujung jari dari air lautan. Karena semuanya 'kembali' kepada Allah. Maka pluralisme (menyamakan semua agama) menjadi lanjutan terhadap gagasan begini dimana yang penting dan utama adalah Pencipta, dan semua ciptaan adalah sama hadir di alam maya hanya karena kehendak Allah Ta'ala.

Maka paham ini, tanpa dibarengi dengan pemahaman dan kepercayaan syariat, dapat membelokkan akidah. Pada zaman dahulu, para waliullah di negara-negara Islam Timur Tengah sering, apabila di dalam keadaan begini, dianjurkan untuk tidak tampil di khalayak ramai. Tasawuf falsafi diperkenalkan di Nusantara oleh Fansuri dan Syekh Siti Jenar. Syekh Siti Jenar kemudian dieksekusi mati oleh dewan wali (Wali Songo). Ini adalah hukuman yang disepakati bagi pelanggaran syariat, manakala hakikatnya hanya Allah yang dapat maha mengetahui.

\subsection{Ajaran Tasawuf Nurruddin Ar-Raniry a. Tentang Tuhan}

Pendirian Ar-Raniry dalam masalah ketuhanan pada umumnya bersifat kompromis. Ia berupaya menyatukan paham mutakalimmin dengan paham para sufi yang diwakili Ibn „Arabi.19 Ia berpendapat bahwa ungkapan” wujud Allah dan Alam Esa” berarti bahwa alam ini merupakan sisi lahiriah dari hakikatnya yang batin, yaitu Allah, sebagaimana yang dimaksud Ibn „Arabi. Namun, ungkapan itu pada hakikatnya menjelaskan bahwa alam ini tidak ada. yang ada hanyalah wujud Allah Yang Esa. Jadi tidak dapat dikatakan bahwa alam ini berbeda atau bersatu dengan Allah. Pandangan Al-Raniry hampir sama dengan Ibn „Arabi bahwa alam ini merupakan tajalli Allah. Namun, tafsiranya di atas membuatnya terlepas dari label panteisme Ibn „Arabi.

\section{b. Tentang Alam}

Ar-Raniry berpandangan bahwa alam ini diciptakan Allah melalui tajalli. Ia menolak teori Al-faidh (emanasi) Al-Farabi karena hal itu dapat memunculkan pengakuan bahwa alam ini qadim sehingga menjerumuskan pada kemusyrikan.21 Alam dan falak, menurutnya, merupakan wadah tajalli asma dan sifat Allah dalam bentuk yang kongkrit. Sifat ilmu bertajalli pada alam akal; Nama Rahman ber-tajalli pada arsy; Nama Rahim ber-tajalli pada kursy; Nama Raziq ber-tajalli pada falak ketujuh; dan seterusnya.

\section{c. Tentang Manusia}

Manusia, menurut Ar-Raniry, merupakan mahluk Allah yang paling sempurna di dunia sebab manusia merupakan khalifah Allah di bumi yang dijadikan dengan citra-Nya. Juga, karena ia mazhhar (tempat kenyataan asma dan sifat Allah paling lengkap dan menyeluruh). Konsep insan kamil, katanya, pada dasarnya hampir sama dengan apa yang telah digariskan Ibnu „Arabi. 


\section{d. Tentang Wujudiyyah}

Inti ajaran wujudiyyah, menurut Ar-Raniry, berpusat pada wahdat Al-wujud dapat membawa kepada kekafiran. Ar-Raniry berpandangan bahwa jika benar Tuhan dan mahluk hakikatnya satu, dapat dikatakan bahwa manusia adalah Tuhan dan Tuhan adalah manusia dan jadilah seluruh mahluk sebagai Tuhan. Semua yang dilakukan manusia, baik buruk atau baik, Allah turut serta melakukanya. Jika demikian halnya, maka manusia mampu mempunyai sifat-sifat Tuhan.

\section{e. Tentang Hubungan Syari'at dan Hakikat}

Pemisahan antara syariat dan hakikat, menurut Ar-Raniry merupakan sesuatu yang tidak benar. Untuk menguatkan argumentasina, ia mengajukan beberapa pendapat pemuka sufi, diantaranya adalah Syeikh Abdullah Al-Aydarusi yang menyatakan bahwa tidak ada jalan menuju Allah, kecuali melalui syariee at yang merupakan pokok dan cabang islam. 25

\subsection{Peranan Nuruddin Ar-Raniry Di Banda Aceh}

Ar-Raniry berperan penting saat berhasil memimpin ulama Aceh menghancurkan ajaran tasawuf falsafinya Hamzah Fansuri yang dikhawatirkan dapat merusak akidah umat Islam awam terutama yang baru memeluknya. Tasawuf falsafi berasal dari ajaran al-Hallaj, Ibnu Arabi, dan Suhrawardi, yang khas dengan doktrin Wihdatul wujud ( Menyatunya Kewujudan) di mana sewaktu dalam keadn sukr(,,mabuk dalam kecintaan kepda Allah Ta ${ }^{e c}$ ala) dan Fana ${ }^{e e}$ fillah (,hilange bersama Allah), seseorang wali itu mungkin mengeluarkan kata-kata yang lahiriyahnya sesaat yang menyimpang dari syarieeat Islam.

Syaikh al-Raniry mengemukan fatwa pengkafirannya terhadap wujudiyah Aceh tidak hanya dalam khutbah-khutbah tetapi juga di dalam kitab-kitabnya seperti Tibyan fi ma'rifat al-Adyan, Hill al-Zill, Jawahir al-Ulum fi Kasyf al-Ma'lum, Hujjat al-Shiddiq li Daf'il alZindiq dan Ma'al-Hayah li Ahl al-Mamat dan lain sebagainya.

Inti penentangan al-Raniry dapat diringkas sebagai berikut: Hamzah Fansuri sesat karena berpendapat bahwa alam, manusia, dan Tuhan itu sama saja, paham wujudiyah Hamzah Fansuri sama dengan panteisme karene dia melihat Tuhan sepenuhya immanen(tasbih), padahal Tuhan itu transenden(tanzih), Hamzah Fansuri dan Syams al-Dhin, seperti golongan falasifah, meliputi bahwa al-Qurean itu mahluk, Hamzah Fansuri percaya bahwa alam itu qadim atau abadi, Hamzah Fansuri dikatakan mengemukakan ungkapanungkapan syathiyat seperti al-Hallaj dan Bayazid dalam keadaan tidak mabuk(sukr), Hamzah Fansuri cenderung mengabaikan syariee at, bahkan menganjurkan pengikutnya meninggalkan syarie at.

Perbedaan pemikiran sufistik antara Hamzah dan Syamsuddin dengan Nuruddin di atas mendorong ulama India untuk datang dan menetap di Aceh. karena itu ada beberapa alasan kedatangan Nuruddin ke Aceh. Ia datang untuk pertama kalinya ke Aceh mungkin karena mengikuti jejak pamanya Syekh Muhammad Jailani bin Hasan bin Muhammad Hamid arRaniry yang tiba di Aceh pada tahun 1588 M. Nuruddin menulis kitab Ash-Shirathal Mustaqim ( jalan yang lurus) yang mulai di tulisnya pada tahun $1044 \mathrm{H}$ atau tahun 1633M, yaitu sebelum ia menetap di Aceh. Kedua, Nuruddin datang ke Aceh mungkin juga disebabkan oleh Krisis Akidah yang telah terjadi di dalam masyarakat Aceh, yaitu pada masa pemerintahan Sultan Iskandar Muda yang memerintah tahun 1603-1636 M. Nuruddin datang ke Aceh mungkin disebabkan oleh perebutan kekuasaan, baik jabatan sultan maupun penasihat sultan.

Kedatangan Nuruddin ke Aceh selain disebabkan oleh beberapa hal sebagaimana telah dikemukan di atas juga disebabkan oleh unsur politik, yaitu perebutan kekuasaan dalam jabatan penasihat sultan ataupun jabatan sultan. Karena itu, perbedaan pemikiran dan keyakinan (perang nonfisik) antara Hamzah dan Syamsuddin dengan Nuruddin sekarang ini pengaruhnya sudah berkurang dan berbagai kalangan telah menerima perbedaan itu, terutama 
kalangan Kampus. Akan tetapi, secara politis (perang secara fisik) sampai sekarang pengaruhnya masih terasa.

\subsection{Sanggahan Terhadap Doktrin Wahdatul Wujud Hamzah Fansuri}

Adapun masalah yang terkandung dalam filsafat mistik Hamzah yang disanggah oleh Nuruddin Ar-Raniry dapat disimpulkan sebagai berikut:

a. Hamzah mengajarkan ajaran wujudiyyah dalam arti Tuhan berada dalam kandungan alam ini. Artinya, Tuhan adalah hakikat fenomena alam empiris.

Menurut Nuruddin Ar-Raniry, menyatakan emanasi Tuhan sama saja dengan menyamakan Tuhan dengan alam/makhluk adalah sesat.31 Karena dalam pandangannya, Tuhan adalah Transenden yang tidak mungkin dapat ber-maqam dalam diri makhluk, sehingga Ia sama sekali berbeda dengan makhluk. Ar-Raniry menuduh Hamzah telah melakukan hal ini, katanya:

"bahwa segala arwah dan segala sesuatu itu daripada suku-suku Allah dari kerana Ia berbuat dan menjadikan segala sesuatu. Maka perbuatannya dan yang demikiannya itu jadi daripada-Nya dan kembali pula kepada-Nya jua. Maka segala makhluqat itu suku-suku daripada Allah."

Dari kutipan di atas jelaslah bahwa dalam pandangan Ar-Raniry, Hamzah berkeyakinan kalau Allah dan alam pada hakikatnya sama. Hamzah telah menempatkan alam dan Tuhan memiliki hakikat yang sama dan tidak ada bedanya. Hal ini lebih jelas dengan perumpamaan Hamzah tentang Tuhan dengan sebiji pohon kayu. Ar-Raniry mengatakan:

"Maka sekarang kunyatakan pula kepadamu setengah daripada iectiqad kaum wujudiyyah yang dibawa angin, yaitu Hamzah Fansuri dan Syamsuddin as-Sumatrani dan segala yang mengikut keduanya. Kata Hamzah Fansuri dalam kitabnya yang bernama muntahi pada merencanakan sabda Nabi (man 'arafa nafsahu faqad 'arafa rabbahu) barang siapa mengenal dirinya bahwasanya mengenal Tuhannya; arti mengenal Tuhannya dan mengenal dirinya, yakni Diri (kuntu khanzan makhfiyyan) itu dirinya, dan semesta sekalian alam dalam ilmu Allah. Tamsil seperti biji dan pohon; pohonnya dalam biji itu lengkap serat dalam biji itu. Maka nyatalah dari perkataan wujudiyyah itu bahwa seru semesta alam sekaliannya ada lengkap berwujud dalam Haq Ta "eala. Maka keluarlah alam dari padanyaNya seperti pohon keluar kayu keluar daripada biji. Maka ieitiqad yang demikian itu kufur."

b. Hamzah mengatakan bahwa nyawa itu bukan Khalik dan bukan makhluk. Ar-Raniry mengutip perkataan Hamzah dalam kitabnya Asraru'l-'Arifin sebagai berikut:

"Adapun barang yang jadi di bawah kun fayakun, syu'un zati dinamai ahlussuluk. Kata ahlussuluk nyawa amr Allah itu belum datang ke bawah ,kun fayakun kata ahlussuluk, titah di atas , jadi kau ${ }^{e e}$, menjadi! apabila di atas ,,jadi kau! "ee menjadi khalik pun tiada, makhluk pun tiada, Khalik pun tiada, karena ia titah Allah Subhanahu wa ta ${ }^{e c}$ ala.

Ar-Raniry menolak perkataan Hamzah bahwa semua ahlussuluk berpendapat seperti itu, yakni nyawa manusia itu bukan Khalik dan bukan makhluk. Menurut Syekh Nuruddin, semua ulama berpendapat bahwa nyawa itu makhluk karena dijadikan Allah dengan ciptaan kun. Syekh Nuruddin mengiyakan, dan karena itu nyawa manusia itu baharu. Sedangkan Hamzah mengatakan bahwa nyawa itu Amr Allah, bukan ciptaan dari firman Kun, dan karena itu ia qadim berbeda dengan ciptaan alam ini.

c. Hamzah mengatakan bahwa Alquran itu makhluk.

Menurut Ar-Raniry, Hamzah keliru menyatakan Alquran sebagai makhluk sebagaimana kaum Qadariyah dan Muetazilah dalam sejarah Islam. Ar-Raniry mengatakan: 
"Dan setengah daripada mereka itu (Qadariyyah, Mu'tazilah) ietiqadnya bahwa Alquran itu makhluk. Maka iectiqad yang demikian itu kufur, seperti sabda Nabi saw: "Man qala inna Alquran makhlukun fahuwa kafir". Demikian lagi ietiqad Hamzah Fansuri dalam kitab yang berjudul Asrarul 'arifin, katanya bahwa Alquran yang dibawa Jibril itu dapat dikatakan makhluk.

d. Hamzah mengatakan bahwa nyawa berasal dari Tuhan dan akan kembali bersatu denganNya, seperti ombak kembali ke laut.

\subsection{Tentang hal ini Syekh Nuruddin menulis sebagai berikut:}

"Dengar pula olehmu kata kaum wujudiyyah yang mulhid pada menafsirkan firman Allah: Ya ayyatuha'l-nafsul mutmainnah irji'i ila rabiki rädiyatan mardiyyah, yakni datang nafs mutma'in itu pun daripada allah jua dan kembali nya pun kepadaNya jua; demi Allah!, jangan lagi syak. Soal betapa arti firman Allah tae ala itu? Jawab : adapun artinya itu seperti semisal ... ombak itu daripada laut jua dan kembalinya pun kepadanya jua. Artinya karena wujud kita itu wujud Allah, nyakni zat Allah Ta ${ }^{e e}$ ala jua demi Allah tiada lain ... demi Allah manakala luputlah kita daripada pengetahuan dan dari pada pihak ta'ayyun dan daripada pihak batin kitapun, maka sampailah kepada kunhi kita, yakni zat Allah Ta"eala." Apa yang disebut oleh syekh Nuruddin itu memang ada ungkapan dalam kitab Muntahi, di mana Hamzah menulis sebagai berikut:

"Ya ayyatuhannafsul muthmainnah, irji'i ila rabbika radhiyatan mardhiyyah; fa dkhuli fi' ibadi wadkhuli jannati. Hai segala kamu bernyawa muthmainnah! Pulanglah kamu kepada Tuhan kamu radhi Ia akan kamu. Maka masuklah surga- Ku, hai hamba-hamba-Ku! Artinya datangnya pun daripada laut, pulangnya pun kepada laut jua ...; karena pada orang berahi wasal, jannah itulah yang dikatakan dalam ayat: fa dkhuli fi'ibadi wa dkhuli jannati. Pulanglah ia kepada tempat kuntu khanzan makhfiyyan."

Selanjutnya Syekh Nuruddin mengatakan bahwa penafsiran yang dilakukan Hamzah Fansuri terhadap firman Allah Q.S. Al-Baqarah ayat 156, dapat menimbulkan pengingkaran adanya surga dan neraka seperti yang diajarkan dalam agama.

"Maka dimaknakan oleh kaum Wujudiyyah yang zindik itu seperti makna pada ayat "inna li'l-lahi wa inna ilaihi raji'an", adalah maksud mereka itu bahwa alam itu keluar daripada Wujud Allah dan kembali ia jua menjadi bersatu dengan Dia. Karena pada mereka itu tiada surga dan neraka dan tiada ada pada mereka itu Tuhan, hanya ia bertuhankan dirinya sendiri."

Sedangkan arti yang diberikan oleh para mufassirin terhadap ayat-ayat tersebut, kata Syekh Nuruddin, adalah bahwa manusia itu milik Allah dan jua segala amalnya akan kembali kepada-Nya. Jika amalnya baik, ia akan dimasukkan ke dalam surga, dan jika buruk dimasukkan kedalam neraka.

\section{Kesimpulan}

Dari uraian di atas dapat diambil beberapa kesimpulan sebagai berikut:

1. Syeikh Nuruddin ar-Raniry adalah ulama penasehat Kesultanan Aceh pada masa kepemimpinan Sultan Iskandar Tsani (Iskandar II). Syaikh Nuruddin diperkirakan lahir sekitar akhir abad ke-16 di kota Ranir, sebuah Kota Pelabuhan Tua di Pantai Gujarat, India, dan wafat pada 21 September 1658. Pada tahun $1637 \mathrm{M}$, ia datang ke Aceh, dan kemudian menjadi penasehat kesultanan di sana hingga tahun $1644 \mathrm{M}$.

2. Nuruddin Ar-Raniry, merupakan salah satu orang Gujarat yang sangat berperan terhadap perkembangan Aceh prioritasnya dalam bidang keagamaan yang mengambil spesifikasi 
dalam bidang tasawuf, Ar-Raniry sangat dikenal di Aceh terutama ketika ia menentang paham wujudiyyah Hamzah Fansuri yang menjadi keyakinan masyarakat Aceh pada masa itu.

3. Ar-Raniry merupakan tokoh pembaruan di Aceh. Ia mulai melancarkan pembaharuan Islam di Aceh setelah mendapat pijakan yang kuat di Istana Aceh. Pembaruan utamanya adalah memberantas aliran wujudiyah yang dianggapnya sebagai aliran sesat.

4. Menurut Ar-Raniry, berpusat pada wahdat Al-wujud dapat membawa kepada kekafiran. Ar-Raniry berpandangan bahwa jika benar Tuhan dan mahluk hakikatnya satu, dapat dikatakan bahwa manusia adalah Tuhan dan Tuhan adalah manusia dan jadilah seluruh mahluk sebagai Tuhan. Semua yang dilakukan manusia, baik buruk atau baik, Allah turut serta melakukanya. Jika demikian halnya, maka manusia mampu mempunyai sifat-sifat Tuhan

5. Di antara karya-karya yang pernah ditulis Ar-Raniry adalah: Ash-Shirah Al-Mustaqim (fiqih berbahasa melayu), Bustan As-Salatin fi Dzikir Al-Awwalin wa Al-Akhirin (Bahasa Melayu), Durrat Al-Fara'idh bi Syarhi Al-'Aqa'id (akidah, bahasa Melayu), Syifa' Alqulub (cara-cara berzikir, bahasa Melayu).

Setelah mengetahui kisah, biografi, kehidupan dan pemikiran Syeikh Nuruddin ArRaniry di atas, maka perlu kita meneladani sifat beliau yang taat dan tegas dalam bidang agama, sosial dan bahkan politik. Begitu juga dalam hal akidah tetap istiqamah pada paham Ahlus Sunnah wal Jamaeeah. Semoga kita menjadi hamba-Nya yang bertakwa dan menjadi ummat terbaik akhir zaman.

\section{Daftar Pustaka}

Abdul Hadi, Tasawuf Yang Tertindas, Jakarta: Paramadina, 2001.

Abdul Majid, Karakteristik Pemikiran Islam Nuruddin Ar-Raniry, Jurnal Substantia, Volume 17 Nomor 2, Oktober 2015. Fakultas Ushuluddin dan Filsafat, UIN Ar-Raniry

AhmadDaudy, Syekh Nuruddin Ar-Raniry; Sejarah Hidup, Karya, dan Pemikirannya, Banda Aceh: Ar-Raniry; Pusat Penelitian dan Pengkajian Kebudayaan Islam (P3KI), 2006.

Ahmad Daudy, Syaikh Nurruddin ar-Raniri: Sejarah, Karya, dan Sanggahan terhadap Wujudiyyah di Aceh, Bulan Bintang, 1983.

Azyumardi Azra, Jaringan Ulama Timur Tengah dan Kepulauan Nusantara Abad XVII \& VXIII: Akar Pembaharuan Islam Indonesia Edisi Parenial, Jakarta: Kencana, 2013.

Jajat Burhanudin, Ulama \& Kekuasaan: Pergumulan Elite Muslim dalam SejarahIndonesia, Jakarta: Mizan Publika, 2012.

Mohd. Kalam Dau , "Al-Tibyan fi Ma"rifah al-dyan, agama-agama Samawi dan sektesektenya (Analisis Aliran Wujudiyah Hamzah Fansury) “, Banda Aceh: PeNA, 2011.

Musyrifah Sunanto, Sejarah Peradaban Islam Indonesia, Jakarta: PT RajaGrafindo Persada, 2005.

Sangidu, Wachdatul Wujud, Yogyakarta: Gama Media, 2000.

Sehat Ihsan Shadikin, Tasawuf Aceh, Banda Aceh: Bandar Publishing, 2009.

Sirajuddin Abbas, Ulama Syafi'I dan Kitab-kitabnya dari Abad ke Abad, Jakarta:Pustaka Tarbiyah, Cet. 1975.

Syekh Naquib Al-Attas, Raniri and the Wujudiyyah of 17 th. Century Aceh, Singapore, MMBRAS III, 1996.

https://id.wikipedia.org/wiki/Nuruddin_al-Raniri diakses pada tanggal 09 oktober 2016 http://www.acehbooks.org/pdf/ACEH_03426.pdf 